\title{
In vitro regeneration protocol of Rauvolfia serpentina $\mathrm{L}$.
}

\author{
S. Khan*, T. A. Banu, S. Akter, B. Goswami, M. Islam, U. Hani and A. Habib \\ Plant Tissue Culture Section, Biological Research Division, Bangladesh Council of Scientific and Industrial Research, \\ Dhanmondi, Dhaka-1205
}

Received: 14 June 2017

Revised: 04 October 2017

Accepted: 31 Janurary 2018

DOI: http://dx.doi.org/10.3329/bjsir.v53i2.36674

\begin{abstract}
An efficient in vitro regeneration system was developed for Rauvolfia serpentina $\mathrm{L}$. through direct and indirect organogenesis from nodal and leaf explants. Among the different growth regulators, MS medium supplemented with $2.0 \mathrm{mg} / 1 \mathrm{BAP}, 0.5 \mathrm{mg} / \mathrm{l} \mathrm{IAA}$ and $0.02 \mathrm{mg} / 1 \mathrm{NAA}$ found best for the multiple shoot formation from nodal segments. In this combination $98 \%$ explants produced multiple shoots and the average number of shoots per explants is $13 \cdot 4$. The frequency of callus induction and multiple shoot induction from leaves was highest $88 \%$ in MS medium supplemented with $2.0 \mathrm{mg} / \mathrm{l}$ BAP, where mean number of shoots/explants was 12.5 . The highest frequency of root induction $(80 \%)$ and mean number of roots/plantlets (10) were obtained on half strength of MS medium containing $0.2 \mathrm{mg} / \mathrm{l}$ IBA. The rooted plantlets were transferred for hardening following acclimatization and finally were successfully established in the field.
\end{abstract}

Keywords: Rauvolfia serpentina L.; Nodal segment; Leaf explants; Multiple shoot; Callus induction

\section{Introduction}

Rauvolfia serpentina L. (Fam.: Apocynaceae) is an important medicinal shrub (Nathan Kline, 1954). In Bangladesh, it is commonly known as Sarpagandha. Rauvolfia is diverse, popularly known as 'snake-weed genus' which includes about 50 species. It is a traditional herbal plant native to Indian subcontinent and East Asian countries. This plant is rich in many secondary metabolites such as alkaloids, flavonoids, glycosides, phenols, resins, saponins, tannins etc. The root of $R$. serpentina is a rich source of indole NAA alkaloids viz. serpentine, reserpine, recinnamine, ajamaline, ajmalicine, deserpidine and yohimbine. Rauvolfia alkaloids belong to the general class of medicines called "anti-hypertensive" and commonly used to treat cardiovascular diseases (Anitha and Kumari, 2006), arrhythmia (Kirillova et al., 2001), and hypertension (Von Poser et al., 1990). Alkaloids of this plant have a great medicinal value and used to treat various psychiatric diseases (Bhatara et al., 1997), breast cancer (Stanford et al., 1986), promyelocytic leukemia (Itoh et al., 2005) and others. It is also well known for its antimicrobial, antifungal, anti-inflammatory, anti-proliferative, anti-diuretic and anti-cholinergic activities.
For therapeutic properties, $R$. serpentina is threatened due to overexploitation by the local and tribal people, coupled with limited cultivation (Gupta, 1988). The International Union for the Conservation of Nature and Natural Resources (IUCN) has kept this plant under endangered status (Jain et al., 2003). So, there is an urgent need to conserve this plant with great medicinal importance. Conventionally, $R$. serpentina reproduces via viable seeds, but low percentage of seed germination, short viability of seed, scanty and delayed rooting of seedlings limit its natural propagation. In this context, an alternative way for farming and conservation of the plant could be based on its in vitro regeneration. Plant tissue culture is a well-known biotechnological tool for the mass propagation of rare, endangered and threatened medicinal plants which are facing the danger of extinction. In vitro propagation is also a powerful tool for the production of medicinal secondary metabolites as well as for the purpose of conservation (Islam et al., 2010; Nadeem et al., 2000) and commercialization. The development of plant tissue culture system can also offer an opportunity for producing drugs from the roots in the laboratory. 
There are a number of reports on in vitro regeneration of $R$. serpentina (Susila et al., 2013; Bhatt et al. 2008) but still those lack any common regeneration protocol of the plant. Therefore, the present study was undertaken to develop an efficient protocol for rapid in vitro regeneration of $R$. serpentina using node and leaf explant as an initial plant material by optimizing the growth regulators such as auxins and cytokinins.

\section{Materials and methods}

Two types of explants namely, nodal segment and young leaf were used in the present experiment. The explants were collected from $R$. serpnetina grown in the research fields of BCSIR, Dhaka. The experiment was conducted at Plant tissue culture section, Biological Research Division, BCSIR Laboratories Dhaka. After collection, the explants were primarily kept under running tap water for 5 minutes. The primary surface sterilization was carried out by treating the samples with mild detergent (Tween-20) and washed with tap water for 30 minutes. After that, explants were surface sterilized with $70 \%(\mathrm{v} / \mathrm{v})$ ethanol for $1 \mathrm{~min}$, followed by $0.1 \%$ $\mathrm{HgCl}_{2}$ through gentle shaking for $5 \mathrm{~min}$ and rinsed three times with autoclaved distilled water. Isolated explants were inoculated and cultured on MS (Murashige and Skoog, 1962) media containing BAP, NAA, IAA and Kn singly or in combinations for direct and indirect (through callus) in vitro regeneration of shoots. In vitro regenerated shoots were sub-cultured regularly to fresh medium at an interval of 21-28 days for further multiplication. Elongated shoots were separated and cultured on rooting medium for root formation. About 2-3 cm long shoots were separated and cultured on rooting medium containing full and half strengths of MS without hormonal supplement or with different concentrations of IBA. All in vitro grown cultures were maintained under illumination on a $16 \mathrm{~h}$ photoperiod at $25 \pm$ $2^{\circ} \mathrm{C}$. The well rooted plantlets were then kept in room temperature for 2-3 days and transferred to plastic pot containing garden soil and compost in a ratio of 2:1 and was moistened them adequately for proper hardening.

\section{Results and discussion}

In this study, it was found that nearly medium aged explants were suitable for callus and shoot induction. The explants were cultured on MS medium supplemented with various concentrations of BAP, IAA, NAA, and Kn singly or in combinations, to observe their effect on initiation and development of shoots. Effectiveness of MS medium for optimum shoot multiplication in different species have also been noted by various workers (Akter et al., 2013; Jain et al., 2003; Baksha et al., 2007; Bhatt et al., 2008; Singh et al.,
2009; Panwar et al., 2011; Susila et al., 2013; Rani et al., 2014; Rashmi et al., 2016).

Among the media components used in this study, the highest percentage of responsive explants $(98 \%)$ was obtained on MS medium supplemented with $2.0 \mathrm{mg} / \mathrm{l} \mathrm{BAP}+0.5 \mathrm{mg} / 1 \mathrm{IAA}+$ $0.02 \mathrm{mg} / \mathrm{l} \mathrm{NAA}$ and shoot initiation was found to occur within 5-12 days of inoculation in the medium (Fig. 1a). The highest average shoot number 13.4 was obtained in this combination using nodal explants (Table-I, Figs. 1b, 1c). The regenerated shoots were found to elongate within 45 days. Rani et al. (2014) also showed that the best shoot elongation of $R$. serpentina was found on MS media supplemented with $3.0 \mathrm{mg} / 1 \mathrm{IAA}$ plus $3.0 \mathrm{mg} / 1 \mathrm{BAP}$ with a mean number of shoot 6.50. Such direct organogenesis were also reported from nodal explants in other important medicinal plant species such as Santalum album (L.) (Janarthanam and Sumathi, 2011), Eclipta alba (L.) (Sharma et al., 2013). For leaf explants, mean number of shoots was 11.2 on MS medium supplemented with $2.0 \mathrm{mg} / 1 \mathrm{BAP}+0.5 \mathrm{mg} / \mathrm{l} \mathrm{IAA}$ $+0.02 \mathrm{mg} / 1$ NAA (Table-I, Fig.1d). Pandiyan and Selvaraj (2012) showed that $1.0 \mathrm{mg} / \mathrm{l} \mathrm{BAP,} 1.0 \mathrm{mg} / \mathrm{Kn}$ and $1.0 \mathrm{mg} / \mathrm{l}$ NAA was the most suitable combination for obtaining maximum number of shoots from Bacopa monnieri (L). Singh et al. (2009) reported shoot regeneration of $R$. serpentina was highest $75 \%$ on MS medium supplemented with BAP $2.5+$ IAA $0.4 \mathrm{mg} / 1$ from leaf explants.

In case of leaf explants, best callus induction and multiple shoots formation was found on MS with $2.0 \mathrm{mg} / 1 \mathrm{BAP}$. In this combination (MS with $2.0 \mathrm{mg} / \mathrm{l} \mathrm{BAP}$ ) callus initiation occurred within 13-22 days of inoculation (Fig. 1e) and multiple shoots were produced from the callus within 7 days. Here $88.88 \%$ leaf explants showed regeneration response and the highest mean number of shoots/explants was 12.5 (Table-I, Fig. 1f). The efficiency of BAP for shoot culture initiation and multiplication in $R$. serpentina has also been reported elsewhere (Jain et al., 2003; Alatar et al., 2012). In MS with $2.0 \mathrm{mg} / \mathrm{l}$ BAP supplemented medium, nodal explants also showed good regeneration response (Fig. 1g). Here shoot initiation was found to occur within 5 - 15 days of inoculation. In addition, the percentage of responsive explants was $93.33 \%$ and the mean number of shoots was 12.3 (Table-I). For further multiplication, regenerated shoots were sub-cultured on the same media. The stimulating effect of BAP on multiple shoot formation has been reported for several medicinal plant species (Wang et al., 2004; Islam et al., 2010; Jaheduzzaman et al., 2012). In both the explants of $R$. serpentina, MS medium supplemented with $2.0 \mathrm{mg} / \mathrm{l}$ BAP $+0.5 \mathrm{mg} / \mathrm{K} \mathrm{Kn}$ also showed better regeneration response. The percentage of responsive explants was $96.67 \%$, in case of nodal explants and for leaf explants it was $80 \%$ (Table-I). 
Table I. Best hormonal combinations for shoot regeneration of $R$. serpentina from nodal and leaf explants

\begin{tabular}{|c|c|c|c|c|c|c|c|}
\hline \multicolumn{4}{|c|}{ Hormonal supplements (mg/l) } & \multirow{2}{*}{$\begin{array}{l}\text { \% of explants } \\
\text { showed regener } \\
\text { ation from } \\
\text { node explants }\end{array}$} & \multirow{2}{*}{$\begin{array}{l}\% \text { of explants } \\
\text { showed regeneration } \\
\text { after callus } \\
\text { induction from } \\
\text { leaf explants }\end{array}$} & \multicolumn{2}{|c|}{$\begin{array}{l}\text { Average no. of shoot } \\
\text { buds/explants after } \\
45 \text { days }\end{array}$} \\
\hline BAP & NAA & IAA & $\mathrm{Kn}$ & & & $\begin{array}{l}\text { Node } \\
\text { explants }\end{array}$ & $\begin{array}{l}\text { Leaf } \\
\text { explants }\end{array}$ \\
\hline 0.5 & - & - & 0.2 & 73.33 & 50.00 & 9.8 & 5.6 \\
\hline 1.0 & - & - & - & 80.00 & 66.00 & 10.5 & 10.3 \\
\hline 1.0 & - & - & 0.5 & 83.33 & 73.33 & 11.3 & 7.9 \\
\hline 2.0 & - & - & 0.2 & 90.00 & 80.00 & 11.9 & 9.1 \\
\hline 2.0 & - & - & - & 93.33 & 88.88 & 12.3 & 12.5 \\
\hline 3.0 & - & - & - & 86.67 & 76.47 & 11.6 & 10.6 \\
\hline 2.0 & - & - & 0.5 & 96.67 & 80.00 & 12.6 & 9.1 \\
\hline 2.0 & - & 0.5 & - & 95.00 & 88.33 & 12.2 & 9.5 \\
\hline 2.0 & 0.2 & - & - & 90.00 & 88.33 & 9.8 & 7.6 \\
\hline 2.0 & 0.5 & - & - & 80.00 & 70.00 & 9.1 & 8.3 \\
\hline 2.0 & 0.2 & 0.02 & - & 90.00 & 75.00 & 10.2 & 8.1 \\
\hline 2.0 & 0.5 & 0.02 & - & 98.00 & 81.25 & 13.4 & 11.2 \\
\hline
\end{tabular}

Table II. Effect of half and full strength MS medium with different concentrations of IBA on root induction from in vitro regenerated shoots of $R$. serpentina

\begin{tabular}{llllll}
\hline $\begin{array}{l}\text { Media } \\
\text { combination } \\
(\mathrm{mg} / \mathrm{l})\end{array}$ & $\begin{array}{l}\text { No. of shoots } \\
\text { inoculated }\end{array}$ & $\begin{array}{l}\text { No. of shoots } \\
\text { showed root } \\
\text { induction }\end{array}$ & $\begin{array}{l}\text { of responsive } \\
\text { explants }\end{array}$ & $\begin{array}{l}\text { Days required } \\
\text { for root } \\
\text { initiation }\end{array}$ & $\begin{array}{l}\text { Mean No. roots } \\
\text { per plants }\end{array}$ \\
\hline MS & 10 & 3 & 30 & $16-20$ & 5 \\
$1 / 2 \mathrm{MS}$ & 10 & 2 & 20 & $17-22$ & 7 \\
$1 / 2 \mathrm{MS}+0.1 \mathrm{IBA}$ & 10 & 5 & 50 & $14-20$ & $14-18$ \\
$1 / 2 \mathrm{MS}+0.2$ IBA & 10 & 8 & 80 & & 10 \\
\hline
\end{tabular}



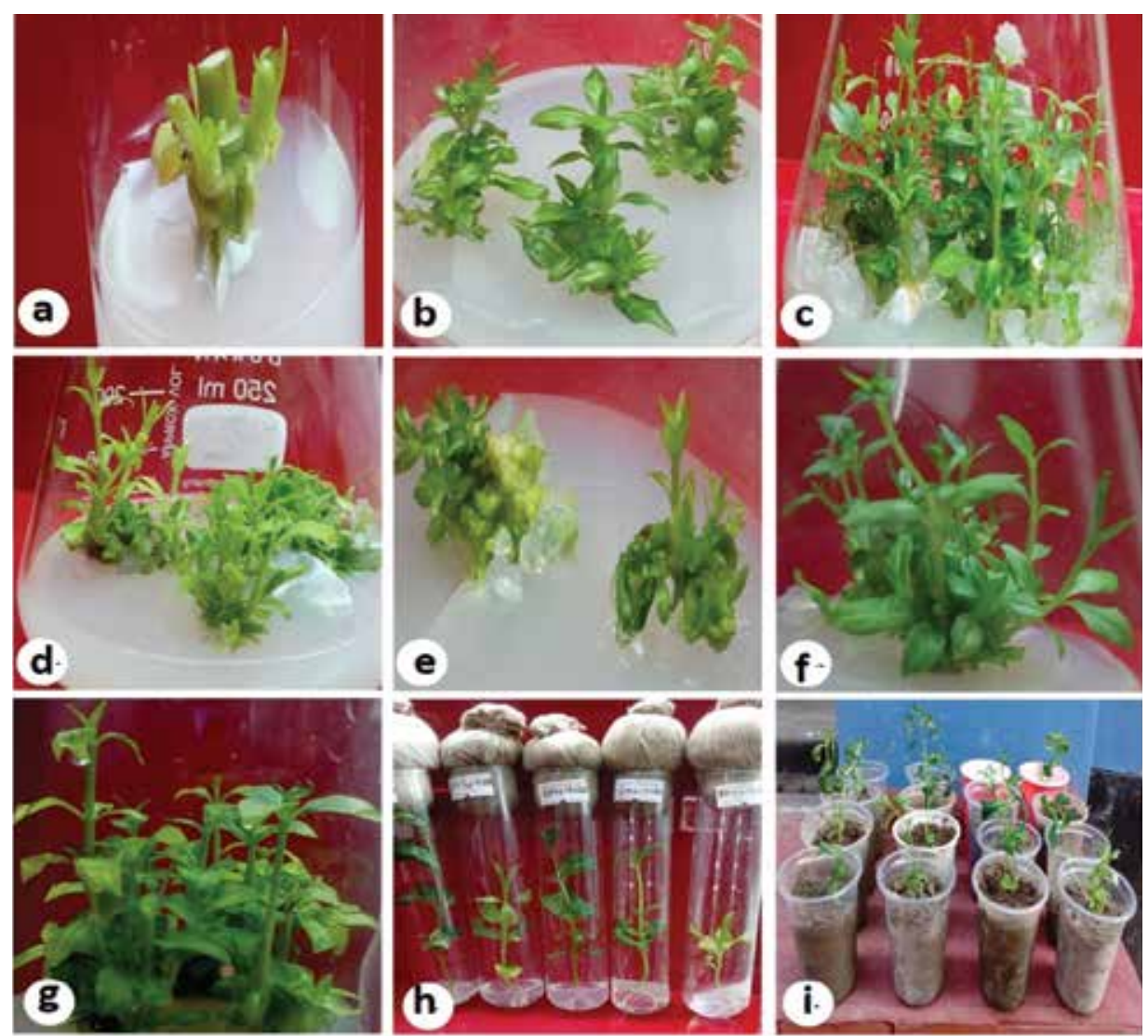

Fig. 1. (a-i). Different stages of in-vitro regeneration of Rauwolfia serpentine (L.); a. Initiation of shoot from nodal explants on MS with $2.0 \mathrm{mg} / \mathrm{l} \mathrm{BAP}+\mathbf{0 . 5} \mathrm{mg} / \mathrm{l}$ IAA $+\mathbf{0 . 0 2} \mathrm{mg} / \mathrm{l}$ NAA; $b$. Multiple shoot formation from node on same media composition. $\mathrm{c}$. Elongation of shoots from nodal explants on same media composition as MS with $2.0 \mathrm{mg} / \mathrm{l} \mathrm{BAP}+0.5 \mathrm{mg} / \mathrm{IAA}+0.02 \mathrm{mg} / \mathrm{l} \mathrm{NAA}$; d. Multiple shoots formation from leaf explants on MS with $2.0 \mathrm{mg} / \mathrm{l} \mathrm{BAP}+0.5 \mathrm{mg} / \mathrm{I}$ IAA $+0.02 \mathrm{mg} / \mathrm{l}$ NAA; e. Multiple shoots initiation from leaf explants on MS medium supplemented with $2 \mathrm{mg} / \mathrm{l} \mathrm{BAP;}$. Elongation of multiple shoots from leaf explants on same media composition; g. Elongation of multiple shoots on same media composition as MS medium supplemented with 2 $\mathrm{mg} / \mathrm{l}$ BAP but in case of nodal explants; $h$. Root formation from in-vitro regenerated shoots on half strength of MS medium with $0.2 \mathrm{mg} / \mathrm{I} \mathrm{IBA}$; i. Acclimatization of regenerated plantlets in plastic pots

Shoot initiation was found to occur within 6 - 14 days of inoculation for nodal explants, whereas leaf explants showed callus initiation and shoot multiplication after 15-24 days of inoculation. Rashmi et al. 2016 also used MS media supplemented with various concentrations of NAA and Kn for callus induction and production of multiple shoot regeneration from leaf and stem explants of $R$. serpentina. MS medium supplemented with different concentration and combination of BAP and NAA were applied in this present experiment. It was observed that various combinations of BAP and NAA showed good response for shoot initiation as well as multiplication. Shoot induction and multiplication from nodal explants were significantly influenced by MS media supplemented with $2.0 \mathrm{mg} / \mathrm{l} \mathrm{BAP}$ and $0.2 \mathrm{mg} / \mathrm{l} \mathrm{NAA}$ where $90 \%$ of plants showed proliferation and mean number of shoots/explants were 9.8 (Table-I). In case of leaf explants maximum shoots (9.1) were obtained on MS $2.0 \mathrm{mg} / 1$ BAP and $0.5 \mathrm{mg} / 1 \mathrm{NAA}$ supplemented media. Panwar et al. (2011) observed that maximum shoots of $R$. serpentina (25.4 per culture) were obtained from the callus inoculated in shooting medium containing BAP $2.0 \mathrm{mg} / \mathrm{l}+\mathrm{NAA} 0.5 \mathrm{mg} / 1$. MS medium supplemented with $1.5 \mathrm{mg} / \mathrm{l} \mathrm{BA}$ and $0.2 \mathrm{mg} / 1 \mathrm{NAA}$ elicited the maximum number of shoots (4 multiple shoots) from nodal explants (Salma et al., 2008). Susila et al. (2013) observed best shoot proliferation (92\%) in MS medium containing $0.1 \mathrm{mg} / 1 \mathrm{NAA}$ and $2.5 \mathrm{mg} / 1 \mathrm{BA}$. Along with other combinations, MS media containing BAP and IAA were also effective for shoot initiation and multiplication. MS medium supplemented with different concentrations and combinations of BAP (1.0- $2.0 \mathrm{mg} / \mathrm{l})$ and IAA $(0.2$ and 0.5 $\mathrm{mg} / \mathrm{l})$ were applied to examine their effects on shoot regeneration from nodal and leaf explants of $R$. serpentina. 
But best response towards multiple shoot regeneration was achieved on MS media supplemented with $2.0 \mathrm{mg} / 1 \mathrm{BAP}$ and $0.5 \mathrm{mg} / \mathrm{l} \mathrm{IAA}$ in both the explants of nodal and leaf explants (Table-I). In case of nodal explants shoot regeneration was $95 \%$ and the average number of shoot was 12.2 . But in case of leaf explants shoot regeneration was $88.33 \%$ and the average number of shoot was 9.5. Singh et al. (2009) reported shoot regeneration of $R$. serpentina was highest $75 \%$ on MS medium supplemented with $2.5 \mathrm{mg} / \mathrm{l} \mathrm{BAP}+0.4 \mathrm{mg} / \mathrm{l} \mathrm{IAA}$.

When both the explants (leaf and nodal explants), were cultured on series of various hormonal combinations, a differential response of explants with regard to shoot induction and multiplication was observed. Of the two explants nodal segments were found to be the best sources of multiple shoot induction (Table-I). Some author also suggested the same type of explants for propagation of other important medicinal plants such as, Pterocarpus santalinus (Warakagoda and Subasinghe, 2013) and Boerhaavia repens (L.) (Rownaq Hossain, 2010). Root induction at the base of in vitro regenerated shoots is an indispensible step to get a complete plantlet. So, after shoot elongation about $3-4 \mathrm{~cm}$ long shoots were separated and cultured on freshly prepared rooting medium containing full and half strength of MS medium with different concentrations of IBA (0.1 and $0.2 \mathrm{mg} / \mathrm{l})$ for induction and development of roots. In the present study, the best response towards root induction was observed on half strength of MS with $0.2 \mathrm{mg} / 1$ IBA (Fig.1h, Table-II). The mean number of root per explants was 10 . In this hormonal combination, roots were formed at the base of the cut end of in vitro grown shoots. Roots were healthy and took less time than others for root induction and development. Susila et al. (2013) reported rooting in $R$. serpentina on half strength of MS medium supplemented with BAP, IBA and NAA. Panwar et al. (2011) reported 100\% of rooting of $R$. serpentina by using half strength of MS medium supplemented with $0.2 \mathrm{mg} / 1 \mathrm{IBA}$ and $0.2 \mathrm{mg} / 1 \mathrm{NAA}$. Jain et al. (2003) reported best rooting of $R$. serpentina by supplemented MS medium with $0.5 \mathrm{mg} / \mathrm{l}$ IBA. After sufficient development of roots, plantlets were successfully transplanted into small plastic pots. The survival rate of the transplanted plantlets was $100 \%$. The plantlets survived in the pots containing soil and compost in the ratio of 2:1 (Fig. 1i). Established plantlets were transferred to the garden soil.

\section{Conclusion:}

In conclusion, it can be mentioned that, the present study describes a reproducible and efficient protocol for mass propagation of this important medicinal plant species. It would also ensure a continuous supply of $R$. serpentina plants in limited time and space for large scale commercial production thereby ruling out the enslavement on natural source to execute the growing demands for the pharmaceutical industry.

\section{References}

Akter S, Banu TA, Habib A, Afrin S, Khatun A, Khan S and Islam S (2013), In vitro clonal multiplication of Aegle marmelos (L.) Corr. through cotyledonary node culture, Banladesh J. Sci. Ind. Res. 48(1): 13-18. DOI: 10.3329/bjsir.v48i1.15408

Alatar AA, Faisal M, Hegazy AK and Hend AA(2012), High frequency shoots regeneration and plant establishment of Rauvolfia serpentina: An endangered medicinal plant, J. Med. Plants Res. 6(17): 3324-3329.

Anitha S and Kumari BDR (2006), Stimulation of reserpine biosynthesis in the callus of Rauvolfia tetraphyla L. by precursor feeding, Afr. J. Biotechnol. 5: 659-661.

Baksha R, Jahan M ,Khatun R and Munshi JL(2007), In vitro Rapid Clonal Propagation of Rauvolfia serpentina (Linn.) Benth, Bangladesh J. Sci. Ind. Res. 42(1): 37-44. DOI: 10.3329/bjsir.v42i1.353

Bhatara VS, Sharma JN, Gupta S and Gupta YK (1997), Images in psychiatry Rauvolfia serpentina: The first antipsychotic, Am. J. Psychiatry. 154: 894-894. DOI: 10.1176/ajp.154.7.894

Bhatt R, Arif M, Gaur A K and Rao PB (2008), Rauwolfia serpentina: Protocol optimization for in vitro propagation. Afr. J. Biotechnol. 7(23): 4265-4268.

Gupta R (1988), Genetic resources of medicinal plant. Indian J. Plant Genet. Res. 1: 98-102. DOI: 10.3329/ bjsir.v47i3.13058

Islam S, Zahan M, Akter S, Banu TA, Habib A, Khan S and Jahana MAA (2010), Mass propagation of Feronia limonia L. through tissue culture. Bangladesh J. Sci. Ind. Res. 45 (1): 75-78. DOI: 10.1021/np058007n 9

Jaheduzzaman, Habib A, Banu TA, Rahman RB, Akter S, Banu TA, Khan S and Islam S (2012), In-vitro Regeneration of an Important Medicinal Plant Centella asiatica (L.) Urban, Banladesh J. Sci. Ind. Res. 47(3): 269-272. DOI: 10.1055/s-2006-957903

Itoh A, Kumashiro T, Yamaguchi M, Nagakura N, Mizushina Y, Nishi Tand Tanahashi T (2005), Indole alkaloids and other constituents of Rauvolfia serpentina, J. Nat. Prod. 68: 848-852. 
Jain V, Singh D, Swarnalata S and Saraf S (2003), In-vitro micro propagation of Rauvolfia serpentina through multiple shoot generation, Anc Sci Life. XXIII(1): 44-49. DOI: 10.3923/ijb.2011.249.254

Janarthanam B and Sumathi E (2011), High Frequency Shoot Regeneration from Inter nodal Explants of Santalum album, L. Int. J. Bot. 7: 249-254.

Kirillova NV, Smirnova MG, Komov VP (2001), Sequential isolation of superoxide dismutase and ajmaline from tissue culture of Rauvolfia serpentina Benth, Appl Biochem Microbiol 37: 181-185. DOI: 10.3923/ajps.2010.285.298

Murashige T and Skoog F (1962), A revised medium for rapid growth and bioassays with tobacco tissue cultures, Physiol. Plant. 15: 443-477. DOI: 10.1111/j.1399-3054.1962.tb08052.x

Nadeem M, Palni LMS, Purohit AN, Pandey H and Nandi SK (2000), Propagation and conservation of Podophyllum hexamdrum Royle: an important medicinal herb, Biol. Conserv. 92: 121-129. DOI: 10.1016/ S0006-3207(99)00059-2

Nathan, Kline NS (1954), Use of Rauvolfia serpentina Benth in neuropsychiatric conditions. Ann N Y Acad. Sci. 59: 107-32. DOI: : 10.1111 /j.1749- 6632. 1954.tb45922.x

Pandiyan P and Selvaraj T (2012), In vitro multiplication of Bacopa monnieri (L.) Pennell from shoot tip and nodal explants, Int $J$ Environ Agric Res. 8(3): 1099-1108.

Panwar GS, Attitalla IH and Guru SK (2011), An Efficient in vitro Clonal Propagation and Estimation of Reserpine Content in Different Plant Parts of Rauwolfia serpentina L., Am.-Eurasian J. Sci. Res. 6(4): 217-222.

Rani A, Kumar M and Kumar S (2014), Effect of growth regulators on micropropagation of Rauvolfia serpentina (L.) Benth, Journal of Applied and Natural Science 6(2): 507-511. DOI: 10.31018/jans.v6i2.490

Rashmi R and Trivedi MP (2016), Rapid in vitro regeneration of an endangered medicinal plant sarpagandha (Rauvolfia serpentina L.), Eur J Pharm Med Res. 3(5): 276-284. DOI: 10.4236/ajps.2012.34053
Rownaq A and Hossain MS (2010), In vitro direct and indirect plantlets regeneration from nodal segment of Boerhaavia repens L. Int Jour Sustain Crop Prod. 5(4): 5-10.

Salma U, Rahman MSM, Islam S, Haque N, Khatun M, Jubair TA and Paul BC (2008), Mass propagation of Rauvolfia serpentina (L.) Benth, Pak. J. Biol. Sci. 11: 1273-1277. DOI: $10.3923 /$ pjbs.2008.1273.1277

Sharma A, Bhansali S and Kumar A (2013), Micropropagation of Ecliptaalba (L.) Hassk. An important medicinal plant of traditional medicine, Int $J$ Life Sci Biotechnol Pharma Res, Vol 3/Issue 2.

Singh P, Singh A, Shukla AK, Singh L, Pande V and Nailwal TK (2009), Somatic Embryogenesis and In Vitro Regeneration of an Endangered Medicinal Plant Sarpgandha (Rauvolfia serpentina L.), Indian J. Sci. 6:74-79.

Stanford JL, Martin EJ, Brintin LA An important medicinal plant of traditional medicine Hoover RN (1986), Rauvolfia use and breast cancer: A case-control study, $J$ Natl Cancer Inst. 76: 817-822. DOI: 10.1093/jnci/76.5.817

Susila T, Reddy GS and Jyothsna D (2013), Standardization of protocol for in vitro propagation of an endangered medicinal plant Rauwolfia serpentina Benth, J. Med. Plants Res. 7(29): 2150-2153. DOI: 10.5897 /JMPR11.066

Von-Poser G, Andrade HH, Da-Silva KV, Henriques AT and Henriques JA (1990), Genotoxic, mutagenic and recombinogenic effects of Rauvolfia alkaloids, Mutat. Res. 232: 37-43. DOI: $10.1016 / \quad 0027-5107$ (90)90107-F-174

Wang J, Seliskar DM and Gallagher JL (2004), Plant regeneration via somatic embryogenesis in the brackish wetland monocot Scripus robustus, Aquatic Bot. 79: 163-174. DOI: 10.1016/j.aquabot.2004.02.003

Warakagoda PS and Subasinghe S (2013), In vitro propagation of Pterocarpus santalinus L. (Red Sandalwood) through tissue culture, J Natl Sci Found 41(1): 53-63. 